\title{
STREET FOOD VENDORS' HYGIENE AND SANITATION PRACTICE IN JAKARTA STREET FOOD COURTS (PUJASERA)
}

\author{
Anton Harianto ${ }^{1}$ \\ Universitas Multimedia Nusantara \\ anton.harianto@umn.ac.id \\ Edvi Gracia Ardani ${ }^{2}$ \\ Universitas Agung Podomoro \\ edvi.gracia@podomorouniversity.ac.id
}

Accepted on 21 Mei 2021

Approved on 19 June 2021

\begin{abstract}
The existence of food street vendors in Jakarta Indonesia has been regulated by a Governor regulation for its improved management and arrangement in 2015. The food street vendors were unregulated and uncontrollable that disturb other street users, become organized with infrastructure support and empowerment plan from the government. The support structure from the local government is to construct food street courts to give basic facilities required for such business. The evolution from unregulated street vendors to a more organized locus for street vendors was supposed to be supported by empowerment. The study aims to investigate how food street vendors feels in facing the changes of business situation in general. For this purpose, a qualitative method with descriptive approach using observations and in-depth interview with the food street vendors. The findings of the research show that the food street vendors feel more confident in selling their food product whereas they have not implemented hygiene and sanitation as it is supposed to be. Thus, it is recommended to enhance the empowerment plan by looking at closely on the communication media to develop the capacity of the food street vendors.
\end{abstract}

Keywords: Food Hygiene; Micro Business; Street Food; Street Vendor Sanitation

\section{INTRODUCTION}

\subsection{Research Background}

Life in the era of pandemic has been difficult for people all around the world to survive in health and economically. People have seen this period as a challenge to find solutions to their own problems, not only personally but also professionally. In business field, the situation is more challenging since it does relate to not only the owner but also to the stakeholders of the business. One of the business which has arisen during the pandemic is food and beverages, more particularly homemade business in Indonesia. Microbusinesses were growing very fast not only the home cooking business but also street food. It is supported by the Government of the Republic of Indonesia who have included encouragement to Micro, Small and Medium Enterprises (MSMEs) to transform after the Corona Covid-19 Pandemic in the Government Work Plan (RKP) 2021 (liputan6.com, 2020).

The pandemic does not stop micro businesses to continue selling their food and beverage. This condition is due to the habit of purchasing prepared food during normal situation, and the street food vendors need to survive. The food and beverage business in Jakarta has grown very fast with the opening of micro business called kaki lima or street food. Street food can be found 
almost in every corner of the street in all areas of Jakarta. With or without relevant knowledge to delivering the food and service to their customers, the food street vendors tend to ignore the hygiene that may impact to the health of their customers (Setyaningrum, 2020).

In Indonesia especially in Jakarta, there has been no regulations being implemented by the government to arrange and organize the existence of food street before 2015. Therefore, the food street vendors were freely moving from one place to another, from one area to another, wherever they felt their target market was situated. This kind of situation used to be favorable for the street vendors as well as for the customers. It helped the vendors to reach their customers out and it also helped the customers to stay home and being offered the food they liked. Some of street vendors prefer to stay in one place because their target market is found surrounding the area. Having street food vendors all over the places is in the city becomes complex problem for the local government to manage. The situation became uncontrollable and too many street food vendors were disturbing other street users. The consequences were various such as unaesthetic issue of the streets, the congestion caused, unmanaged food wastes, and no assurance of hygiene. Kok \& Balkaran (2014) suggested that street vendors in South Africa were more concerned with the convenience and availability of the food rather than its safety. It does indicate that street food tends to provide unsafe food.

A regulation was issued in 2015 by the Governor of The Greater Jakarta (Dinas Perindustrian, Perdagangan, Koperasi dan Usaha Kecil Menengah, 2018) number 10/2015 namely the Structuring and Empowering Food Street Vendors which has the objectives to arrange the food street vendor location management and data collection of the street vendors. Following the issuance of the regulation, the street vendors were identified and registered by the local government with the total thousands of vendors fostered by the local government in 2018. The regulation also arranges the location of the street vendors to be more structured and the vendors are to be empowered to be more rigorous in preparing the food and beverage they offer to their customers. According to the prevailing regulations, coaching the food street vendors are one of the most important keys in the government action plan. Even though this coaching is able to provide benefits for the community at large, it can only be reached out to street vendors who have a strategic place to run their business (Ramadhan, 2015). Empowerment has also been a homework for the government since the vendors have other priorities which are to run their business.

In the initiatives of structuring and empowering food street vendors, the local government was trying to provide areas of location to group street food vendors with sufficient basic infrastructure. There were locations organically formed and some of them were designed specifically for the purpose of the structuring the vendors. Cortese et al. (2016) suggested that the basic requirements for such infrastructure are water connections and food storage to prevent a public health risk to the consumer. The food storage may include stainless steel working table and refrigerator. In line with the basic requirements, the local government of Greater Jakarta started to construct street food court area which is called pujasera to accommodate food street vendors. The construction has been a challenge for the government because the vendors needed to be convinced that they would be able to sell their products with the right requirements more particularly in terms of hygiene and sanitation. Based on the preliminary observation, the pujasera area are well equipped with water connections and setting the waste management with the related division in the local government office.

With such infrastructure, food street vendors should have no issue of hygiene and sanitation on their day-to-day operations. However, it has become another issue when the discussion topic moves to the vendors themselves. At the implementation of the prevailing regulations, structuring plan was to provide the basic facilities in the food street venue or 
pujasera, and it is interesting to find out how the vendors have been practicing their day-to-day operations with the given facilities. People need to know how to avoid unhealthy and unsafety issues in consuming street food (Setyaningrum, 2020). Learning from India, the food street vendors have still no concern in hygiene and sanitation because they use disposable plates and cutleries but reuse them after washing in an inappropriate condition (Basoni, 2021).

Looking at the identified problem, the research question is based on the food street vendors who have been localized into a street food court area being constructed by the local government. It aims to discuss about how the hygiene and sanitation have been practiced by the food street vendors whose location has been accommodated in a pujasera. The empowerment of the street food vendors is supposed to be supported by hygiene and sanitation training. It is very important to verify how the street food vendors are performing their day-today operations, and if the facilities provided are used well. The research has the objectives to find out the practice of the food street vendors more particularly in street food court that has basic facilities such as water connections and relevant working tables. The research was performed in 2021 during the pandemic of Covid-19 in which situation people are considered aware of the importance of hygiene. The locus of the research is in Greater Jakarta area more specifically in the Center and South Jakarta. The purpose of the research is also to give benefits to the government institutions related to the management and arrangement of food and beverage micro businesses that becomes a strong culture in Asia more particularly in Indonesia. Besides, the study will also be beneficial as parameters for academicians who have the passion in the practitioner's capacity development that will help them to build programs.

\subsection{Literature Review}

\subsubsection{Previous Research}

The street food in Indonesia was studied by several researchers. Wirakartakusumah et al. (2014) described that despite the job creation and its impact to the community, Indonesia street food encounters many challenges in its operations such as misuse of additive, abuse of non-food grade chemical, and microbiological issues. The safety aspect of street food is dependent on other factors which are lack of food safety knowledge and the absence for demand on safe and healthy food from consumers (Wirakartakusumah et al., 2014). Comparing to the case in New York, Lucan et al. (2014) suggest that mobile food vendors offer a consistency of food variety but less-healthy prepared and processed items. In addition to that New York mobile vendors provided healthy foods relatively occasionally (Lucan et al., 2014).

\subsubsection{Street Food Vendors}

In food and beverage business, the business of street food vending is categorized as an unorganized sector (Rana \& Ahirrao, 2016). This fact is reinforced by Reddy et al. (2020) suggestion that street food represents the culture of grass-root community that contributes to their family and social entrepreneurialism creating social safety. However, this grass-root condition does not allow them to have high level of awareness food safety standards due to a lack of knowledge because of their temporary and mobile nature of businesses (Reddy et al., 2020).

Rana \& Ahirrao (2016) argued that all components of the society need to work in an integrated manner to improve the quality of the street food vendors, that includes government, education institutions, and other related stakeholders. In this regard, Indonesia have already taken necessary measures to manage the street food by issuing a Governor of Greater Jakarta Regulation No.10 in 2015 Governor of The Greater Jakarta about the Structuring and Empowering Food Street Vendors. It has been shown by the construction of some food street 
infrastructure in certain locations by the local government and in collaboration with private sectors.

Cortese et al., (2016) suggest food street production chain that starts with purchasing, transporting storing, processing or preparing, serving, and cleaning as stated in figure 1 below.

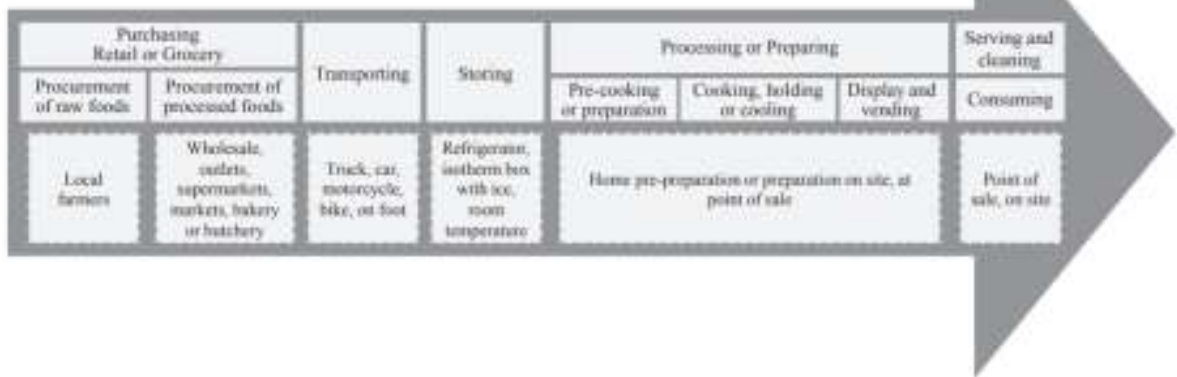

Figure 1. Street Food Production Chain

Source: Cortese et al., 2016

\subsubsection{Hygiene and Sanitation in Food Street Vendors}

Learning from the case of India, major problem of food street vendors is lack of proper knowledge of hygienic food preparation \& serving practices adopted by majority of street food vendors (Rana \& Ahirrao, 2016). Unlike a well-established restaurant business in terms of hygiene and sanitation, Reddy et al. (2020) also argued that food street vendors are not following basic food safety principles like wearing apron, access to tap water, were not able to use soap for cleaning utensils, and many did not have refrigerators to store food. Thus, it explains why food street vendors encounter many issues discovered by Rana \& Ahirrao (2016) that incidences during the working hours could not be avoided when food may get contaminated.

Noticing the changes due to the pandemic situation in China, Song (2020) described that road administration, food safety and environmental protection laws and regulations also have dilemmas on regulating street stall economy. To make those issues balanced, Song (2020) suggested that street vending facilities should be provided in designated venues.

\subsubsection{Conceptual Framework}

The framework of this research is designed to verify and validate the practices in Indonesia more particularly in Jakarta, about how the food street vendors nowadays are managed and how the vendors themselves react and opine about the facilities provided in the food street pujasera to improve their way of selling their product. 


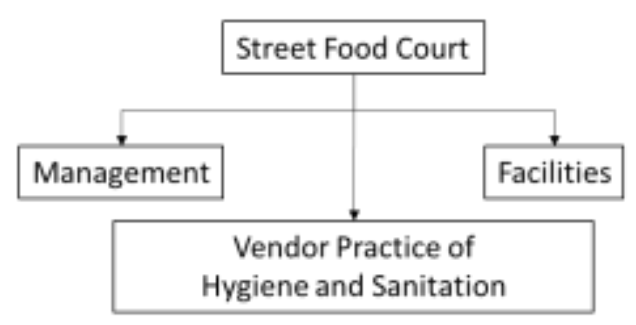

Figure 2. Conceptual Foundation

Source: Author

\section{RESEARCH METHOD}

\subsection{Research Design}

The study is designed to be performed in qualitative method with descriptive approach. The method chosen has the purpose to dig the empathy of the food street vendors which are in a pujasera area, to get their feeling on how their micro businesses are being run with provided basic facilities and facing all the changes. The data collections are through observations and in-depth interviews, that will be supported by secondary data through literature review from the previous research, government regulations, and any other online articles. The result will be validated by documentation being taken during and after the observation to verify the facilities of the venue. The sampling method is snow balling to obtain the key participants that are the most suitable and pertinent to be interviewed. As a multistage sampling technique, snowballing begins with one or a few people or cases and spreads out based on links to the initial cases (Neuman, 2014). The sample size is not defined, because it is directly related to the concept of saturation which is indicated by data replication or redundancy (Marshall et al., 2013).

The research is performed during the pandemic era within the year 2021 with preliminary observation to determine the next step of the research that would enrich the observation and in-depth interview process. It is normal to engage in multiple observations during the course of a qualitative study (Creswell \& Creswell, 2018).

\subsection{Data Collection and Analysis}

The data is collected and analyzed that includes subjectivity of the researchers who have the experience in the food and beverage business and approached the food street vendors as customers. The observation was conducted using ethnography approach in which the street food vendors display habit through external behaviors in social context of how they behave in daily operations of the business externally that displayed behavior alone (Neuman, 2014). A checklist is being established to check the existing facilities in the venues of the food street vendors. To conduct the analysis of the findings, selective coding is involved by scanning all the data and previous codes, looking selectively for cases, and making comparisons after most or all data collection has been completed (Neuman, 2014). The coding begins after the concept of pujasera is developed and identifying the core types of it.

As qualitative research, the data is coded and discussed accordingly in the sense that food street vendors in Jakarta are not originally from the city. These issues impacted the analysis and the result of the study. 


\section{RESULT AND DISCUSSION}

\subsection{Findings from the Observation and Documentation \\ 3.1.1 Types of Food Street}

The research performed started with observations to six locations of food street courts or called pujasera (pusat jajanan serba ada) in the south and center of Jakarta. Those areas are located closed to the center of activity with crowd five to seven days a week. The areas are Melawai (B \& F), Blok S (C), Al-Azhar (D), and Karet Sudirman (A) in the South of Jakarta, as well as Menteng (G) and Bendungan Hilir (E) in the Center of Jakarta. Each location or pujasera has its own characteristics that depend on the creator of the venue.

Subsequent to the findings on the observation, the type of pujasera obviously remains similar in other places. The findings are to categorize pujasera into 4 different characteristics which are facilities provided by a private company, infrastructure constructed with sponsor funding, an area formed based on the demand of the consumers, and vendors freely station in any area but mostly in the same place. The study then continued with the observation of the existing facilities provided in each type of pujasera.

\subsubsection{Basic Facilities}

The result of the observation and in-depth interview reveals that as a mobile business characteristic, the most critical issues are in the storing, processing or preparing, and cleaning processes. These issues were part of the street food production chain suggested by Cortese et al. (2016) and the findings are the needs of stainless steel working tables, refrigerators, and clean water supply. As Cortese suggested water connection is one of the most important part for food street vendors, as in this situation even though clean water supply is provided in the pujasera area the infrastructure is not maximized in several area such as the street pujasera in every type of pujasera is set up differently. The facilities in each pujasera type were found leading to the implementation of hygienity and sanitation of the food street vendors. Below tables (Table 1 and 2) describes the characteristics and existing facilities in each pujasera. Table 1 gives ideas of how each type of pujasera has its characteristics that influence the working environment and cleanliness of the working area of the vendors.

Table 1. Checklist of Pujasera Facilities

\begin{tabular}{|l|l|l|l|l|l|l|}
\hline Pujasera & \multicolumn{1}{|c|}{ Location } & \multicolumn{1}{|c|}{ Layout } & $\begin{array}{c}\text { Waste } \\
\text { Manage-ment }\end{array}$ & $\begin{array}{c}\text { Water } \\
\text { Connection }\end{array}$ & $\begin{array}{c}\text { Working } \\
\text { Environment }\end{array}$ & Cleanliness \\
\hline A & Managed & Well-planned & Well-managed & Ready & Well- managed & Clean \\
\hline B, C & Managed & Well-planned & Well-managed & Ready & Well- managed & Clean \\
\hline D, E & Un-manage & No plan & Self managed & No & Chaotic & $\begin{array}{l}\text { No } \\
\text { guarantee }\end{array}$ \\
\hline F, G & Un-managed & No plan & In-adequate & In-adequate & Chaotic & $\begin{array}{l}\text { No } \\
\text { guarantee }\end{array}$ \\
\hline
\end{tabular}

To help understanding the situation where vendors freely station in any areas, the documentation below tells how water supply is accommodated in buckets placed far behind or next to the stalls as shown in figure 3 . Meanwhile, figure 2 show that the water tap is available in some area (not for every stall). 


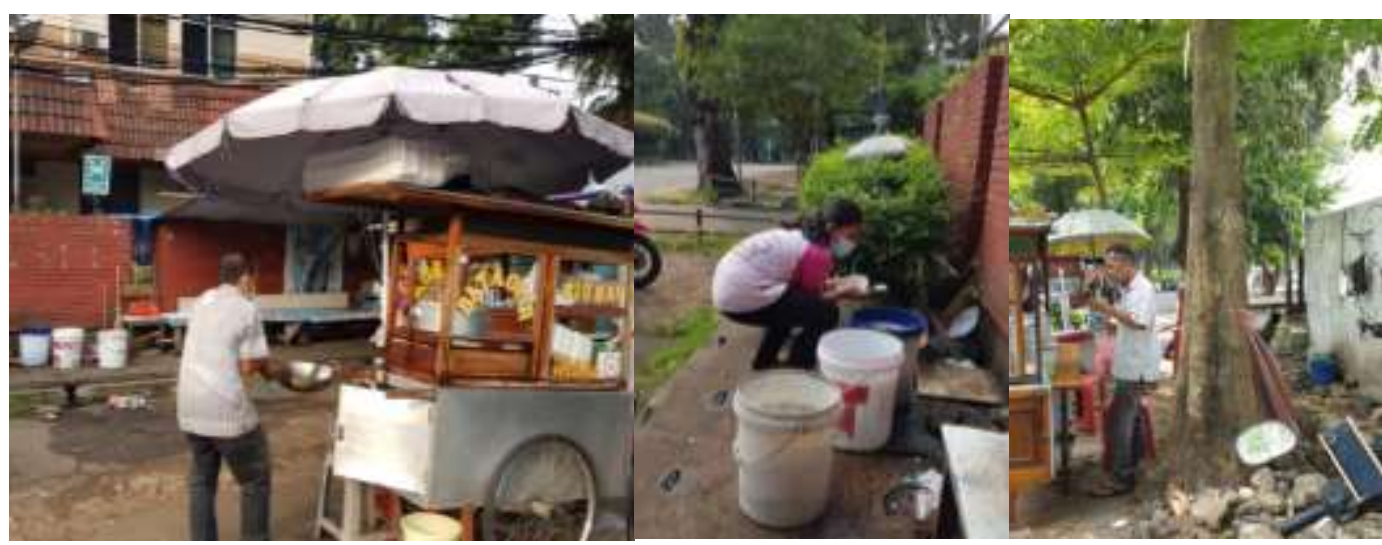

Figure 3. Melawai (F)

Source: Field Observation
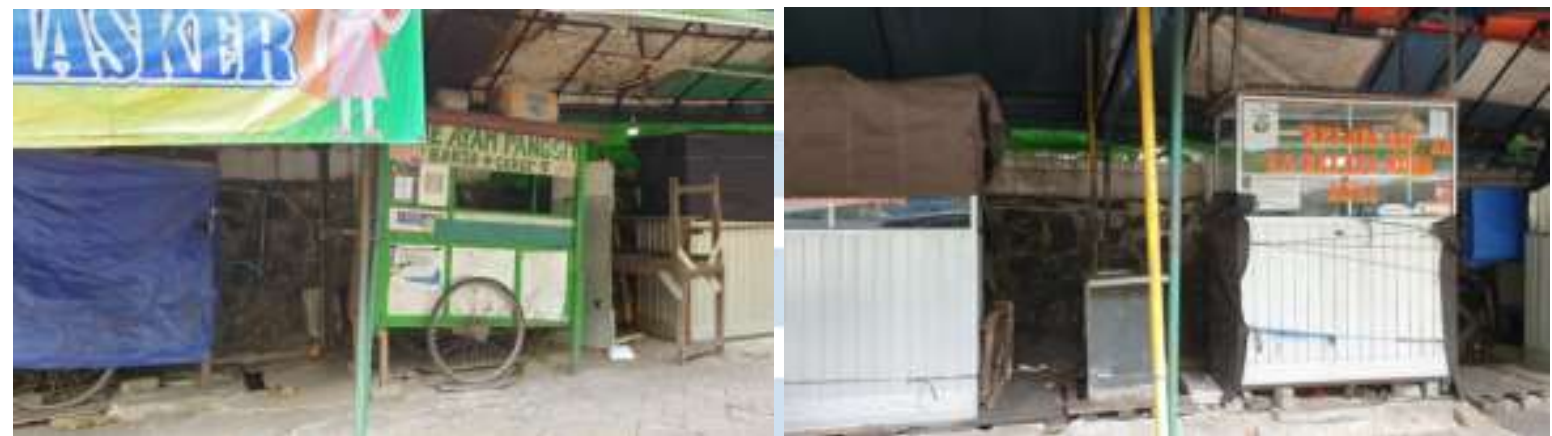

Figure 4. Al Azhar (D) and Bendungan Hilir (E)

Source: Field Observation

The figure 4 shows that the vendors can leave their stalls in the same place. The practice allows the local authority to set up semi-permanent minimum infrastructure with water supply that can be found 1 between 3 to 5 stalls. However, there is no security guarantee for the vendors leaving their assets on the side of a road, nor on the hygiene of the vendors nor the food safety.

Unlike F, D, and E, figure 5 shows that a private area is set dedicatedly for the street food vendors by the office building management, and the vendors can also leave their stalls and equipment in their place. The infrastructure of the area is well designed for the comfort of the consumers as well.
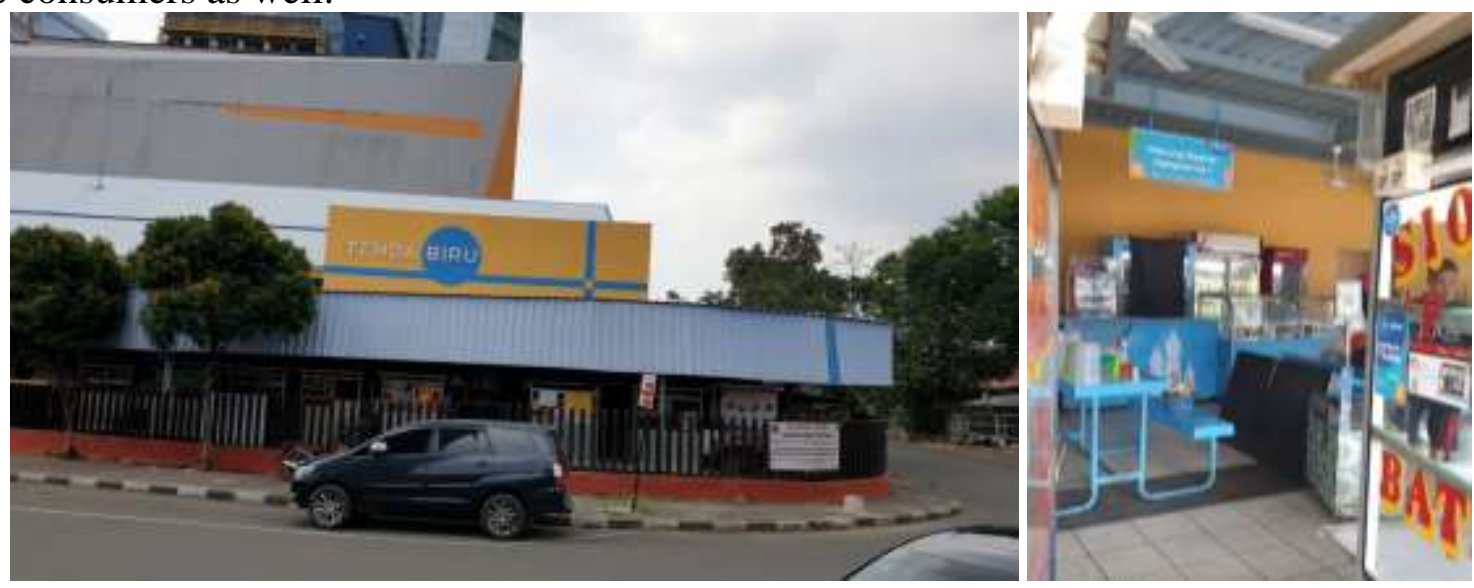

Figure 5. Karet Sudirman (A)

Source: Field Observation 
Observing B, it seems that it is the most well-planned place on the side of Melawai road. The layout is well-planned, and the facilities are provided for each food stall (figure 6) despite the unavailability of the appropriate working tables.
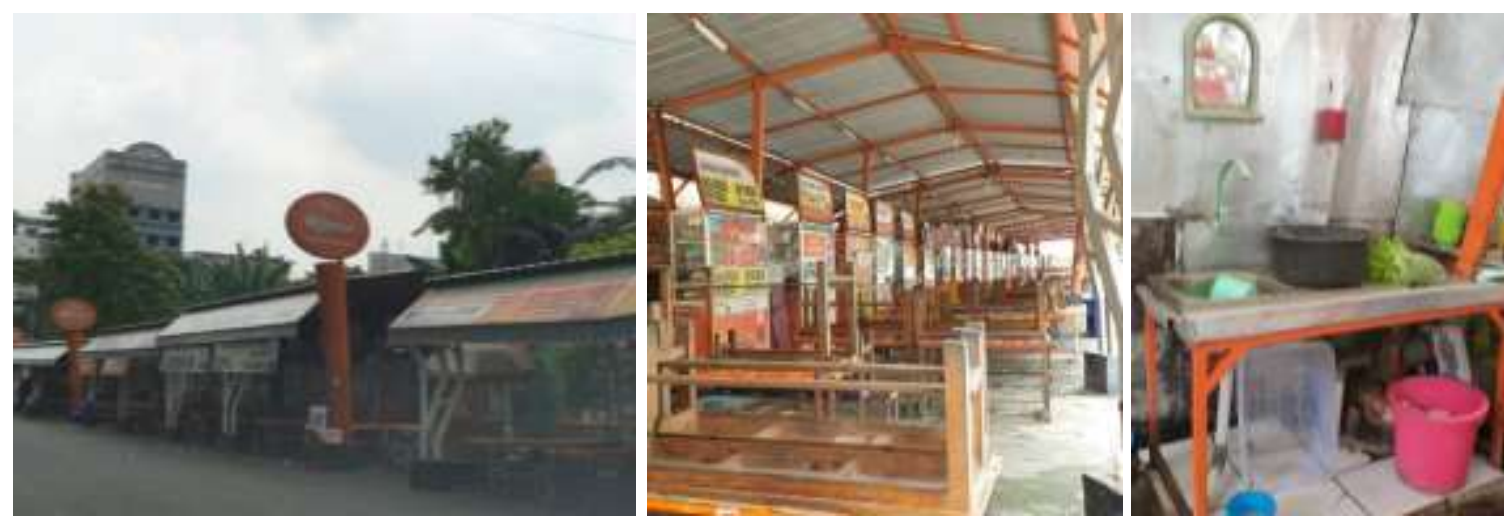

\section{Figure 6. Melawai (B)}

Source: Field Observation

The observation has recorded on how the street food vendors practice the hygiene and sanitation in all areas observed. The checklist of table 2. represents the availability of food street vendor practice of hygiene and sanitation supporting factors such as Water Tap, Storage, Working Table, Equipment and Other supporting tools. They are mostly provided in certain areas and used properly as well as the quality of the hygiene and sanitation.

Table 2. Checklist of Facilities and Practice of Hygiene and Sanitation

\begin{tabular}{|l|l|l|l|l|l|}
\hline \multirow{2}{*}{ Pujasera Area } & \multicolumn{5}{|c|}{ Hygine \& Sanitation Issues } \\
\cline { 2 - 6 } & \multicolumn{1}{|c|}{ Water Tap } & \multicolumn{1}{|c|}{ Storage } & Working Table & $\begin{array}{c}\text { Equipment and } \\
\text { supporting tools }\end{array}$ & \multicolumn{1}{c|}{$\begin{array}{c}\text { Practice and } \\
\text { Quality }\end{array}$} \\
\hline $\mathrm{A}$ & $\begin{array}{l}\text { Provided for } \\
\text { each stall }\end{array}$ & $\begin{array}{l}\text { Provided for } \\
\text { each stall }\end{array}$ & Good condition & Well Equipped & Excellent \\
\hline D, E & $\begin{array}{l}\text { Provided for } \\
\text { each stall }\end{array}$ & $\begin{array}{l}\text { Provided for } \\
\text { each stall }\end{array}$ & Need attention & Need attention & Good \\
\hline F, G & $\begin{array}{l}\text { Provided for } \\
\text { several stalls }\end{array}$ & Inadequate & Inadequate & Inadequate & Inadequate \\
\hline
\end{tabular}

Source: Field Observation

\subsection{Findings from In-depth Interview}

As the result of all observed areas, the ones that can be considered as pujasera are A, $\mathrm{B}, \mathrm{C}, \mathrm{D}$, and $\mathrm{E}$. The first stage of interview was conducted to D and $\mathrm{E}$ with the unsatisfying result because they do not have the capacity to answer the questions in addition to that they have inadequate facilities and infrastructure that aggravate the lack of awareness to practice of hygiene and sanitation.

The in-depth interview was finally conducted to 9 participants from area A, B, and C. During the pandemic, the situation is not favorable for having deep conversation with other places since activities are not normal due to the limitation regulation from the local government. The discussion with the key informants reveals not only issues related to the hygiene and sanitation issues, but also other aspects by empathizing the vendors' condition. 
The findings from the interviews exposes the issues of water supply, waste management, working condition, government supports, and personal hygiene with the following details.

Table 3. Summary of In-depth Interview Result

\begin{tabular}{|l|l|l|}
\hline No & Issues & Findings \\
\hline 1 & Water supply & $\begin{array}{l}\text { Maintain the cleanliness of the prepared food } \\
\text { Maintain the cleanliness of the working area } \\
\text { Preserve raw materials from food contamination } \\
\text { Support to maintain personal hygiene of the vendors }\end{array}$ \\
\hline 2 & Waste management & $\begin{array}{l}\text { Managed by the government } \\
\text { Procedures implemented with schedule } \\
\text { Avoid food contamination }\end{array}$ \\
\hline 3 & Working Condition & $\begin{array}{l}\text { Lack of knowledge in using appropriate tools to prepare food such as } \\
\text { apron, cook hat, appropriate knives and ustensils } \\
\text { Absence of appropriate materials of working tables to keep the } \\
\text { cleanliness } \\
\text { Lack of knowledge in maintaining cleanliness and hazardous issues }\end{array}$ \\
\hline 4 & Government Supports & $\begin{array}{l}\text { Providing food street courts } \\
\text { Lack of capacity development training for the vendors eventhough } \\
\text { socialization was being held }\end{array}$ \\
\hline 5 & Personal Hygiene & $\begin{array}{l}\text { The water supply helps the vendors to keep their personal hygiene } \\
\text { Support the vendors to be more presentable in front of the consumers }\end{array}$ \\
\hline
\end{tabular}
Source: Field Observation

\subsection{Discussion}

\subsubsection{Type of Pujasera}

As stated as findings of this research, the types of street food pujasera can be classififed to 4 (four) different categories which are Sponsored, Private, Freed, and Organic Pujasera. Private pujasera dan Sponsored pujasera have the most adequate infrastructure to implement the hygiene and sanitation while freed and organic pujasera are inadequate. This is due to the unplanned situation of the pujasera by the government because of its characteristic which is answering the demand of the consumers. Thus, the area studied can be classified as follows:

Table 4. Type of Observed Pujasera

\begin{tabular}{|c|l|l|}
\hline No & \multicolumn{1}{|c|}{ Type of pujasera } & Pujasera Area \\
\hline 1 & Sponsored & B, C \\
\hline 2 & Private & A \\
\hline 3 & Organic & D, E \\
\hline 4 & Freed & F, G \\
\hline
\end{tabular}

As the first type of a pujasera B and C, used to be a zoning area for kaki lima or food street during the Sunday mess of a church in nearby area. Based on the in-depth interview with a parking attendant in the area, the numbers of the kaki lima increased through the years because of many other centers of activity such as new offices and women hospital. Thus, the government constructed a pujasera area sponsored by a private beverage company in a 500 square meter area accommodating as many as 40 to 50 stalls with 50 tables and 100 benches 
for the customer area (Nailufar, 2016). This type of pujasera can be labeled as Sponsored Pujasera since the brand of the company is all over the places in the area. The second type pujasera is the case of pujasera A which is situated in the area of an office building. The area is provided by the building management including the venue and all the facilities such as water connection, waste management, consumer area, storage, electricity, and proper preparation area, at the back of the building. This type of pujasera can be labeled as Private Pujasera since it is provided and managed by a private company. The third type of pujasera is the ones located at $\mathrm{D}$ and $\mathrm{E}$ which are organically settled due to the people working and going to school in the surrounding area. It usually starts with 1 or 2 mobile street food vendors then others join because of the demand in the area. This type of pujasera can be labeled as Organic Pujasera due to its characteristics. However, the facilities are minimum because there is no construction for dedicated vending area. Finally, the fourth type is the ones located at the South and Center of Jakarta which are the Kaki lima $\mathrm{F}$ and $\mathrm{G}$ which have no permanent infrastructure and venue for the vendors. The area is used for day activity that requires the vendors to wait until it ends after $5 \mathrm{pm}$. The vendors come to the venue which normal use is a parking area of surrounding buildings and start to install their mobile stalls on it. This unfixed status also provide extremely minimum facilities. This type of pujasera can be labeled as Freed Pujasera, since the vendors are freely to install their stall eventhough the local authority also arrange their presence in the area.

The condition of each pujasera type gives an overview that only sponsored and private pujasera are the most guaranteed in terms of hygiene and sanitation. It does relate to the practice that would require facilities to support the maintenance of the vending places as well as the personal hygiene of the vendors.

\subsubsection{Implementation of hygiene and sanitation}

The findings of the in-depth interview permit to describe on how the street food vendors apply their knowledge of hygiene and sanitation and its impact to their day-to-day operations. Starting with the government initiatives, the facilities were well thoughts to improve the condition of street food vendors in delivering their food and services to the consumers. However, the working condition was felt not being well organized because they do not have enough knowledge about proper equipment and utensils that they should use. Thus, they use the same utensils for all kind of food. Even though the facilities allow them to keep the cleanliness on track, food contamination effects cannot be avoided at certain levels. The importance of water supply at this point is the most important part of street food vendors and only sponsored and private pujasera are able to support them with it. The water supply allows the vendors to pay attention to their personal hygiene and makes them feel being presentable in front of the consumers. This issue is interesting as findings because lack of self-confidence from vendors usually push consumers away. Moreover, the needs of capacity development were expressed between lines by the street food vendors. They actually have a better understanding and knowledge comparing to those in freed and organic pujasera, but it is insufficient according to their thoughts.

\section{CONCLUSION}

\subsection{Conclusion}

The research has revealed the fact that the food street vendors accommodated in a managed pujasera such as sponsored and private ones, have the opportunity to develop their micro business to a higher level of quality and giving confidence to sell their products. It also elevates their knowledge and capacity as food business owners or employees to implement 
better the hygiene and sanitation. The sponsored and private pujasera have more concerns to practice hygiene and sanitation. The needs of capacity development represent the needs of street food education level that requires to be enhanced for the purposes of increasing their income through trustworthiness that might be increased due to the right implementation of the hygiene and sanitation. It does relate to the food safety standard that is produced by wellknowledge personnel with good personal hygiene who wash regularly their hands using water flow connection, use the relevant tools such as apron, cook hat, hand gloves and relevant equipment such as stainless steel made working tables and utensils.

\subsection{Implication and Recommendation}

The research implies to the needs of restructuring freed and organic pujasera with strong plan of developing the vendors capacity and sufficient knowledge about the hazardous issues to prevent food contamination that is dangerous for their consumers. The recommendation for the local authority is to maintain pujasera like the sponsored or private ones and keep the good image of street food. It may also imply to the trustworthiness not only for the local consumers, but it may attract international tourists to push themselves to try local and traditional food at the street food level. It is a challenge for the local government to strengthen the implementation of hygiene and sanitation of the food street vendors by establishing proper venues for them to sell their food and beverage since it has the impact on the healthy and safety of their products. Further regulations are recommended to be considered to strengthening the image but also the food safety issues, not only to street food vendors but also to food and beverage business in general.

\section{REFERENCES}

Basoni, S. (2021, March 27). Jorok! Penjual Makanan Ini Cuci Piring Sekali Pakai Untuk Digunakan Lagi. Food.Detik.Com. https://food.detik.com/info-kuliner/d-5509321/jorokpenjual-makanan-ini-cuci-piring-sekali-pakai-untuk-digunakan-lagi

Cortese, R. D. M., Veiros, M. B., Feldman, C., \& Cavalli, S. B. (2016). Food safety and hygiene practices of vendors during the chain of street food production in Florianopolis, Brazil: A

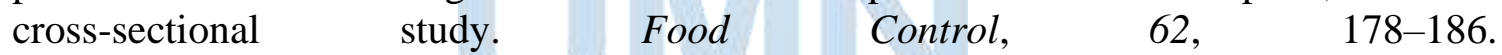
https://doi.org/10.1016/j.foodcont.2015.10.027

Creswell, J. W., \& Creswell, J. D. (2018). Research Design: Qualitative, Quantitative, and Mixed Methods Approaches (5th ed.). https://doi.org/10.1891/9780826146373.0007

Kok, R., \& Balkaran, R. (2014). Street Food Vending and Hygiene Practices and Implications for Consumers. Journal of Economics and Behavioral Studies, 6(3), 188-193. https://doi.org/10.22610/jebs.v6i3.482

liputan6.com. (2020, June 3). 3 Prioritas Pemerintah Dorong Pengembangan UMKM di 2021. Liputan6.Com. https://www.liputan6.com/bisnis/read/4269902/3-prioritas-pemerintahdorong-pengembangan-umkm-di-2021

Lucan, S. C., Maroko, A. R., Bumol, J., Varona, M., Torrens, L., \& Schechter, C. B. (2014). Mobile food vendors in urban neighborhoods-Implications for diet and diet-related health by weather and season. Health and Place, 27, 171-175. https://doi.org/10.1016/j.healthplace.2014.02.009

Marshall, B., Cardon, P., Poddar, A., \& Fontenot, R. (2013). Does sample size matter in qualitative research?: A review of qualitative interviews in is research. Journal of Computer

Information

Systems,

54(1),

11-22. 
https://doi.org/10.1080/08874417.2013.11645667

Nailufar, N. (2016, October 5). Digusur Setahun Lalu, Pujasera Melawai Kembali Dengan Wajah Baru. Kompas.Com. https://megapolitan.kompas.com/read/2016/10/05/12455281/digusur.setahun.lalu.pujase ra.melawai.kembali.dengan.wajah.baru.

Neuman, W. L. (2014). Social Research Methods: Qualitative and Quantitative Approaches. In Pearson Education Limited (Pearson Ne). Pearson.

Ramadhan, A. (2015). Implementasi Model Zonasi Penataan Pedagang Kaki Lima di Kota Bandung. Pandecta: Research Law Journal, 10(1). https://doi.org/10.15294/pandecta.v10i1.4196

Rana, V. S., \& Ahirrao, M. (2016). A Study on Street Food Preparation Practices in Jalgaon City. IBMRD's Journal of Management \& Research, 5(2), 40. https://doi.org/10.17697/ibmrd/2016/v5i2/100477

Reddy, A. A., Ricart, S., \& Cadman, T. (2020). Driving factors of food safety standards in India: learning from street-food vendors' behaviour and attitude. Food Security, 12(6), 1201-1217. https://doi.org/10.1007/s12571-020-01048-5

Setyaningrum, W. C. A. (2020, April 16). Tips Jajan di Pinggir Jalan Agar Tetap Aman dan Sehat. Tirto.Id. https://tirto.id/tips-jajan-di-pinggir-jalan-agar-tetap-aman-dan-sehateNEP

Song, S. (2020). Street stall economy in China in the post-COVID-19 era: Dilemmas and regulatory suggestions. Research in Globalization, 2(1575), 100030. https://doi.org/10.1016/j.resglo.2020.100030

Wirakartakusumah, A., Purnomo, E. H., \& Dewanti-Hariyadi, R. (2014). Safety of Street Food: Indonesia's Experience. Encyclopedia of Agriculture and Food Systems, 5, 75-79. https://doi.org/10.1016/B978-0-444-52512-3.00051-6 